\title{
Patriots and rogues: some Scottish lairds and their libraries.
}

\author{
REID, P.H.
}

2019

This is an Accepted Manuscript of an article published by Taylor \& Francis in Library and Information History on 8/4/2019, available online: http://www.tandfonline.com/10.1080/17583489.2019.1589724. 


\title{
Patriots and rogues: some Scottish lairds and their libraries.
}

Peter H. Reid

Robert Gordon University

\begin{abstract}
This article examines some of the lesser known libraries of Scottish lairds and gentry. The research here formed the basis of the keynote paper delivered at the Library and Information History Group's annual conference 2017 which was held in Dundee, focusing on the theme 'the information landscape in Scotland, 1600-1900. The article draws on archival research, focusing on a number of Scottish lairds and gentry families who developed significant libraries. Some such as William Drummond of Hawthornden and Andrew Fletcher of Saltoun are well-remembered but others such as William Forbes of Tolquhon or the Earls of Seafield have had more modest attention in the scholarly record. The place of the library in the smaller Scottish country house is also addressed from social, cultural as well as architectural terms. Reference is also made to links which existed between Scotland and the Scottish gentry and continental Europe. The article also highlights distinctive differences in approach observed in the Scottish gentry compared with their English counterparts.
\end{abstract}

Keywords: Scotland, private libraries, gentry, lairds, country houses.

\section{Introduction}

The earliest libraries' in Scotland were, as Durkan and Ross highlighted, libraries of manuscripts and inevitably the modern notion of a library only really comes about with the advent of moveable type. Durkan and Ross in their Early Scottish Libraries ${ }^{1}$ explored the ownership of approximately 1,000 volumes, almost all of which were printed 1470-1560; the majority of individuals they studied were, naturally enough, of the same period with only few individuals making it into the seventeenth century. These early individuals in Scotland were not necessarily private book collectors or bibliophiles in the sense that we understand that term today. Many of them, perhaps a clear majority, were clergy and the extent to which they collected for themselves as opposed to assisting their work, is unclear.

Some of these ecclesiastical functionaries, such as William Scheves (d 1497), the Archbishop of St Andrews, may well be noted as collectors of books of note but the degree to which they did this out of a desire to create a personal library (rather than a working library associated with their role) is perhaps questionable. This article may 
be said to provide a commentary on some Scottish lairds and their libraries. This group of gentry were, in all senses, an elite within society and those considered here may not necessarily be said to be typical or representative but they offer an insight, and in many respects a distinctive insight, into private libraries in Scotland during the period 1550 to 1900.

\section{The lairds}

In England, the notion of the squirearchy has lingered long in the collective consciousness and has been extensively investigated by authors from many different perspectives. However, it is only in the last two hundred years or so that the English squirearchy and its more unusual Scottish equivalent, a lairdarchy for want of a better term, have been grouped together under the term of the landed gentry owing much to the publication of Burke's Landed Gentry. ${ }^{2}$ The lairdarchy' may be said to resemble the English squirearchy superficially; yet it is fundamentally different. At the time of the Act of Union of the Parliaments in 1707, Scotland, with a population of 1.25 million people, had 154 Peers (one peer to every 8,000 people), whilst England, with 5.5 people had only 164 Peers (one peer to every 32,000 people). In addition to the titled nobility, Scotland had the whole paraphernalia of the Feudal Baronage and Clan Chieftains. All of these, and even the lesser landed proprietors, habitually used designations which were recognised as making them part of the nobility by the Crown and Courts in Scotland. Of these titles there were over 10,000, so in Scotland one person in every forty-five was either of, or else immediately related to, some such landed 'house'. ${ }^{3}$ Additionally, in common parlance, the word Laird (Scots for Lord but meant more like the French Seigneur) has also come to represent to those grander magnates and landowners many of whom possess hereditary titles with the term 'The Laird' often superseding that of 'the Duke' or 'the Earl' in local parlance.

The majority of lairds were not great territorial grandees; most were modest landowners who, up to the eighteenth century, could often be found still occupying the traditional Scottish tower house. For many, ancestral pride and their sense of place were important. This is partly why so many clung on to those picturesque territorial designations although, as RL Stevenson observed in Kidnapped, these feudal attributions were not universally popular:

'Why then', said he 'what is your name?'

'David Balfour said I: and then thinking that a man with so fine a coat must like fine people, I added for the first time, 'of Shaws'. 
[...] 'My name is Stewart' he said, drawing himself up, 'Alan Breck, they call me. A King's name is good enough for me, though I bear it plain and have the name of no farm-midden to clap to the hind end of it.'"4

Perhaps this can be dismissed as sentimental fiction but as early as the sixteenth century J ohn Leslie (1526-1596) Bishop of Ross (and himself the possessor excellent and cosmopolitan library) noted that pride in ancestry was a Scots trait shared "by the haill people, nocht only the nobilitie". ${ }^{5}$ Although feudal tenure has been abolished in Scotland (but only this century) the inalienable right of landowners to be described 'of' somewhere is legal recognised as part of their surname, Cameron of Lochiel, Brodie of Brodie, or Burnett of Leys. The distinction of being 'of' somewhere rather than 'in' (meaning a tenant or feuar) was significant.

\section{Lairds and their books}

It would be wrong to assume, however, that Scottish lairds were cut off from the cultural awakening which occurred throughout the sixteenth century and even those geographically removed from the traditional centres of power in Scotland were demonstrably interested contemporary developments. William Forbes of Tolquhon (1520-1596) offers some interesting insights into the lairdarchy and their social and cultural pursuits. William 7th Laird of Tolquhon (pronounced 'Ta-hoon') in Aberdeenshire and was a man of some considerable standing in his county. He was over sixty when he embarked reconstructing Tolquhon Castle. The panel over the gatehouse records his activities with precision: "Al this warke excep the auld tour was begun be William Forbes 15 Aprile 1584 and endit be him 20 Ocober 1589." 6

His new castle converted a somewhat cramped old tower house into a spacious mansion in keeping with his aspirations; it was considerably grander and more ambitious than many an Aberdeenshire house. WD Simpson, librarian of Aberdeen University and a great scholar antiquarian, who made a study of Tolquhon, noted that it was "with what seems a touch of pardonable pride" 7 that Forbes noted the accommodation provided in his new mansion; listing in the inventory:

within the wallis of my houiss, tour, and place of Tolquhone, my hallis, gallareis, chalmeris, vardrepe, kitchingis, stabillis, sellaris, lednaris, pantreis, librellis, or uther office houssis quhatsumewer". ${ }^{8}$

In addition to the mention of librellis, Forbes's mortification of his property (3 December 1589) makes it clear that the castle was furnished in keeping with its architectural pretensions; for in the list of his effects are included: "my haill siluer 
wark, buikis, bedding, tapestrie, neprie, timmer wark, artalyerie, wther furniture insycht and plenising quhatsumewer." 9

It is interesting to speculate on whether any significance can be attached to the fact that the Laird listed his "buikis" as being next in value to his plate. There is evidence that William and his eldest son, another William, the $8^{\text {th }}$ Laird (1550-1643), were scholars to some greater degree. The books from Tolquhon eventually ended up at Whitehaugh, a mansion near Alford in West Aberdeenshire where the Forbes family settled after later financial disasters led them to quit Tolquhon. Their descendants at Whitehaugh cherished the Tolquhon books which formed the nucleus of their own small country house library.

James Beattie, (1735-1803) Professor of Moral Philosophy and Logic at Marischal College in Aberdeen, was allowed to borrow books from Whitehaugh. John Forbes Leith of Whitehaugh, writing in a letter dated 26 April 1779, alludes to the fact that he has allowed Dr Beattie to borrow various:

"old musick books which had belong'd to my predecessors, and were found by me among some small remains of a valuable Library, which my Gt. Gt. Grandfather, Wm. Forbes of Tolquhon, possess'd about 200 years ago-I find many of his books mark'd in 1588, he was then aged 38 years, and he lived till $1643^{\prime \prime} .10$

This being the younger William Forbes of Tolquhon. Mr Forbes Leith was clearly interested in his books and in his ancestors' ownership of them for he continues in the same letter "whenever I can recover any bearing his name-or that of Geo. Ogilvie, with whom he was connected, I think them an Acquisition". ${ }^{11}$

The significance of the Tolquhon library emerges in a short commentary which appeared in Notes and Queries. ${ }^{12}$ The notice was submitted by someone only identified by the initials J .M; this was almost certainly J ames Maidment (1793-1879) the antiquarian and literary collector. ${ }^{13}$ The notice describes William the $8^{\text {th }}$ Laird 'a great book collector' and goes on to lament the way in which the TolquhonWhitehaugh library had been sold a few years previously:

the very rare and curious volumes which recently came from the north, and were disposed of in detached portions by Mr Nisbet in Edinburgh at various times, made it a matter of regret that the library was not sold in its entire state with a proper descriptive catalogue. ${ }^{14}$ 
Notes and Queries show that the author is interested in an edition of Erasmus's Apophthegmata, quarto, 1533, on the flyleaf of which was a letter in the hand of Florentius Volusenus (Florence Wolson, the author of the De Tranquillitate Animi) presenting the volume to his friend J ohn Ogilvie, the Parson at Cruden (a few miles from Tolquhon). Wolson reminds Ogilvie of the pleasure he sometimes had derived from Erasmus; and he makes many enquiries about their mutual acquaintances, and in particular sends his love to Master Hector Boece, first Principal of King's College, Aberdeen ${ }^{15}$ who died in 1536 indicating that the letter was written between 1533 and 1536. This volume had come into the possession of the younger William Forbes at Tolquhon by 1588 for his autograph appears on the title page. Another similarly intriguing acquisition by the younger Forbes is a folio edition, (in later binding) of John of Damascus. ${ }^{16}$ On the title-page is inscribed in a singularly fine and, as Simpson puts it, "cultured" hand "Villeame forbes of toiquhone, 1588". Next to this inscription is the autograph of his descendant, Beattie's correspondent, J ohn Forbes Leith of Whitehaugh, and the date 1778. This provides evidence of what is to be found still in many private libraries, multiple autographing of works by successive generations and the sense of heredity which can often be associated with the libraries of the gentry.

This second volume which seems to have avoided the fate of others in the collection has ended up in the Library of the Diocese of Aberdeen and Orkney (in Aberdeen University Library). It is particularly interesting for it also links the Forbes family to another significant private book collector of the time; for underneath the device of the printer Henricus Petrus is the bookplate of Robert Reid, Abbot of Kinloss and later Bishop of Orkney. The bookplate comes from his time as Abbot of Kinloss. ${ }^{17}$ Reid possessed a significant collection of books ${ }^{18}$ and was, in the words of Simpson, "a great lover of books [who] erected a splendid vaulted library at Kinloss". ${ }^{19}$ His books circulated around many collections in the north of Scotland over subsequent centuries. 


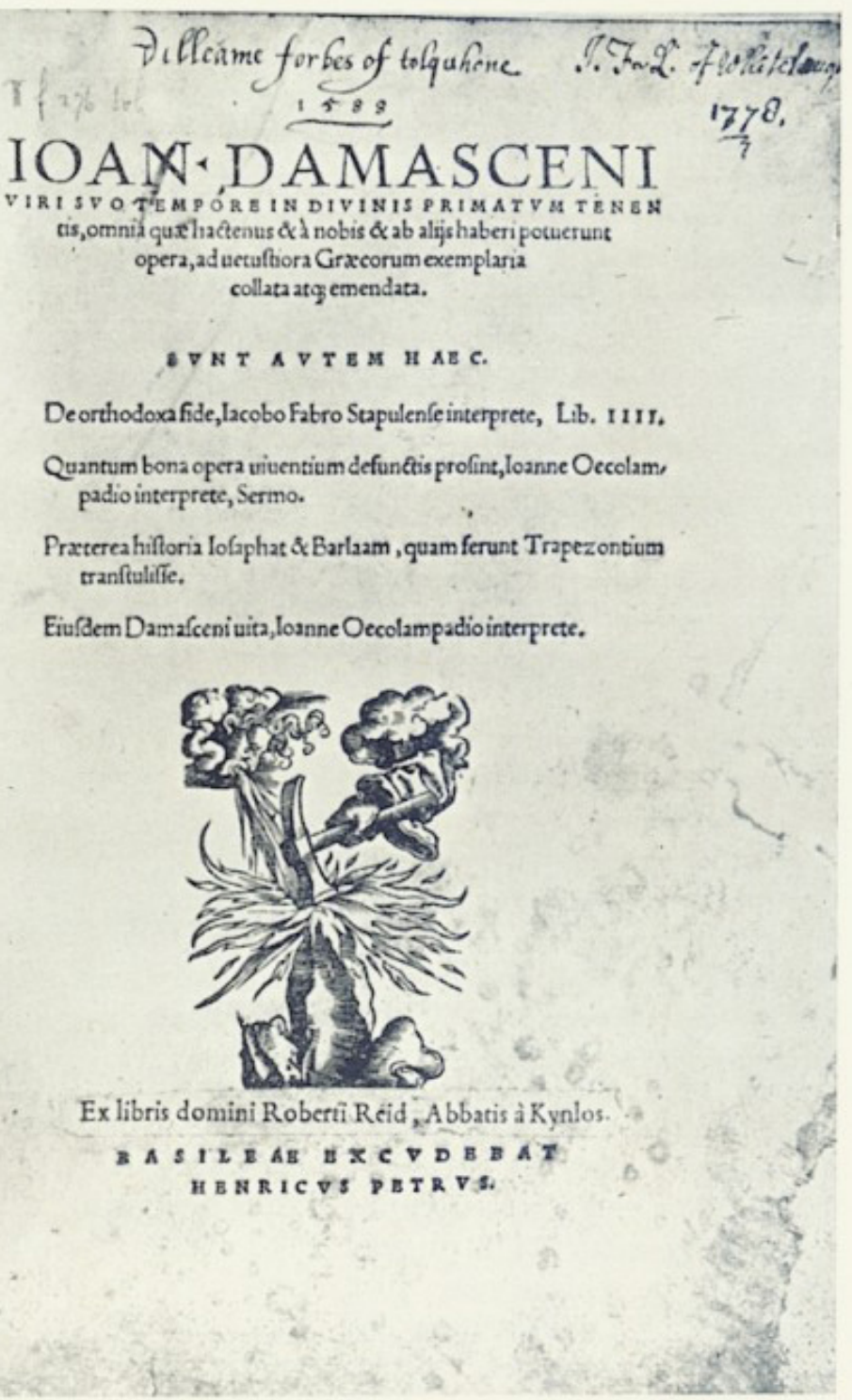

FIG 1: J ohn of Damascus (Basel, 1535) showing the bookplate of Robert Reid, Abbot of Kinloss and Bishop of Orkney as well as the autograph signature of William Forbes of Tolquhon. Courtesy of Sir Duncan Rice Library, University of Aberdeen.

This link with Kinloss which is interesting when considered in conjunction with the previously mentioned copy of Erasmus. Both Wolson and Ogilvie were sons of Moray (midway between Aberdeen and Inverness) and grew up together not very far from Kinloss Abbey. Simpson speculated on this link and on the how the two volumes subsequently came into the possession of the Forbes family:

It will be noted that both books, the Erasmus and the Damascenus, came into the hands of William Forbes in the same year 1588. May the Damascenus also, therefore, have come from the library of J ohn Ogilvie, and may it have been a gift to him from the Abbot of Kinloss? If both Ogilvie and Wolson visited Kinloss between 1533 and 1536, the Damascenus, which was printed in 
March 1535, must have been newly in Reid's hands, and the date of their visit is thus practically restricted to the latter year - a circumstance wholly in accordance with the known fact that Wolson was in London in 1534. (He was back in Paris in September 1535, and on the 19th of that month he started from Chalmont on the journey to Italy that resulted in his appointment as professor of eloquence at Carpentras.) And, if all this be true, how did two books that belonged to Ogilvie come into the possession of the laird of Tolquhon in the year 1588? ${ }^{20}$

His final supposition is perhaps more easily explained and, if the case, would indicate an early example of the movement of books around a family. The younger William Forbes married Janet Ogilvie, daughter of Sir George Ogilvie of Dunlugas in Banffshire. ${ }^{21}$ The Ogilvies formed a close-knit family in Banffshire and Morayshire and John Ogilvie (fl 1570) to whom Wolson gifted the copy of Erasmus, was a kinsman of Lady Tolquhon. ${ }^{22}$

\section{The skied library}

By the time that William Forbes had rebuilt Tolquhon Castle, other lairds were giving thought to the creation of a room to house their books. For the most part, the traditional tower house still predominated in Scotland as fortifications and defence could not yet be safely discarded. Book rooms in these tower houses (or, indeed, in Z-plan castles) are frequently to be found near the top of the house where they were afforded peace and quiet away from the general hurly-burly of everyday domestic life downstairs. This has led to what architectural historians call the 'skied' library, a closet or small cabinet chamber located at the top of the house. McKean noted that the heights' of Elcho Castle in Perthshire contained "several tiny, well-lit, wellwarmed chambers with excellent views" 23 and that these rooms were often referred to as studies and that they might also have been cabinets for books, or library. There were, of course, exceptions to this notion of the skied library particular in larger fortified houses such as Dunottar Castle in Kincardineshire where the small library was sited next to the chapel which extended at some length along the cliffs over the North Sea. The library was to the east of that chapel and from which led the private apartments of the castle's owner, Earl Marischal. ${ }^{24}$

The reasons for these remote, high skied libraries in Scotland are not entirely dissimilar to the reasons for the private closet or cabinet libraries in England. Books were generally perceived as the valuable private property of their owner and so locating them in rooms generally inaccessible to others was a seen as appropriate as well as shrewd. In Scotland this meant locating them on upper floors of tower house, whilst in England it invariably saw them placed in a closet off of the owner's 
bedchamber. ${ }^{25}$ Often the theological works in English collections were located in a closet next to the chapel, if the house possessed one ${ }^{26}$ and it is interesting to speculate on whether the location at Dunottar was consciously emulating an English tradition to some degree although there is no firm evidence to support this.

Even when, in the late seventeenth and eighteenth centuries, the tower house finally gave way to a more recognisable 'country house' form in Scotland, the library often remained tucked away on the upper floors. Traquair House in Peebles-shire is a notable example of this; this beautiful, largely intact library is located on the top floor of the house even though it was assembled in the first forty years of the eighteenth century by the $4^{\text {th }}$ and $5^{\text {th }}$ Earls of Traquair. Apart from its location, the Traquair library is noteworthy for its method of fixed classification with each item accorded a shelf-mark corresponding with a portrait of a philosopher on the curved cornice above the bookshelves. So Fleury's Histoire Ecclesiastio volume VIII is classed at PYTH 4=8 indicating that it is to be found in the bay under Pythagoras, on shelf four, position number eight. Craigston Castle in Aberdeenshire, the seat of the Urquhart family, also contains, to this day, a remarkably intact 'skied' library.

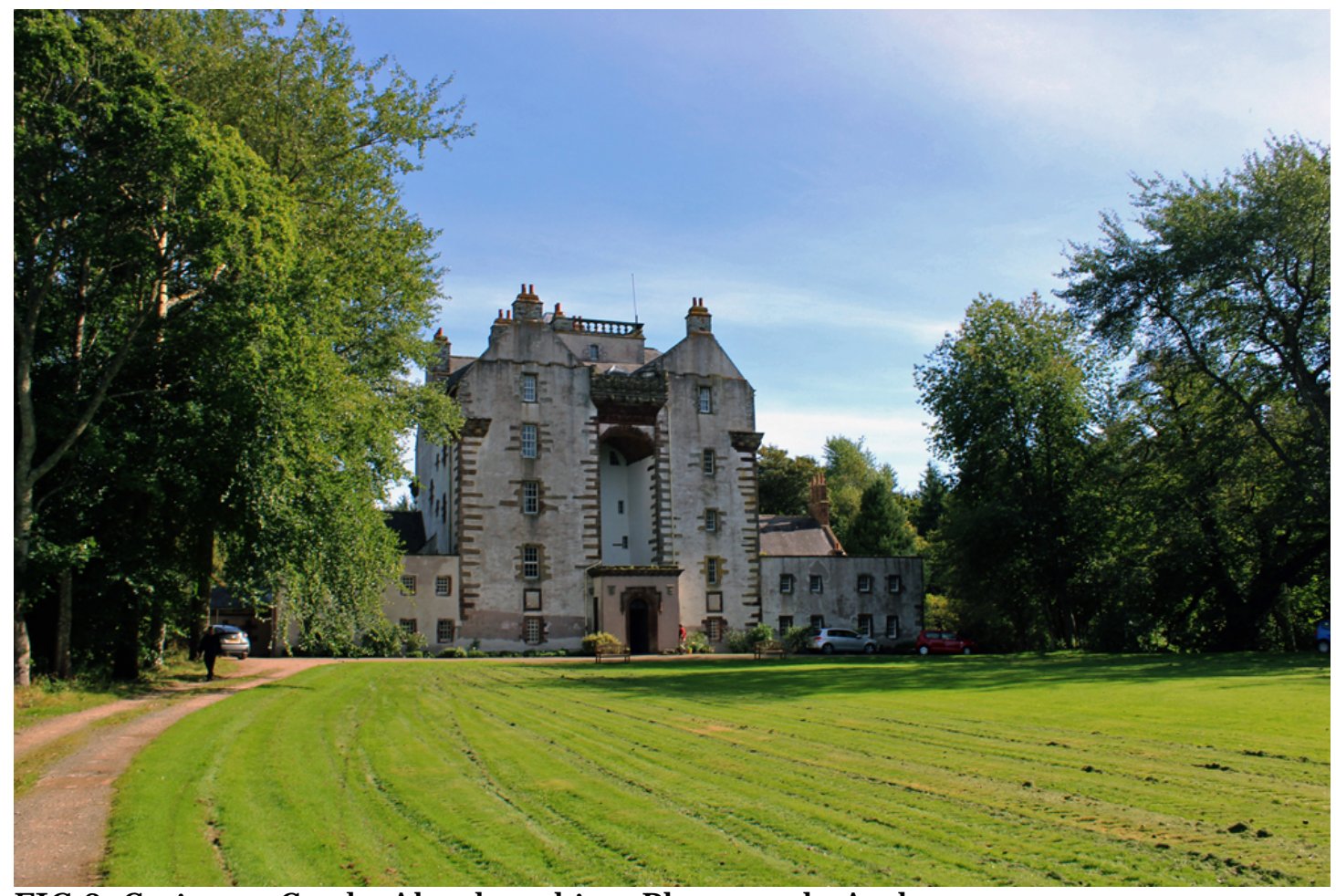

FIG 2: Craigston Castle, Aberdeenshire. Photograph: Author. 


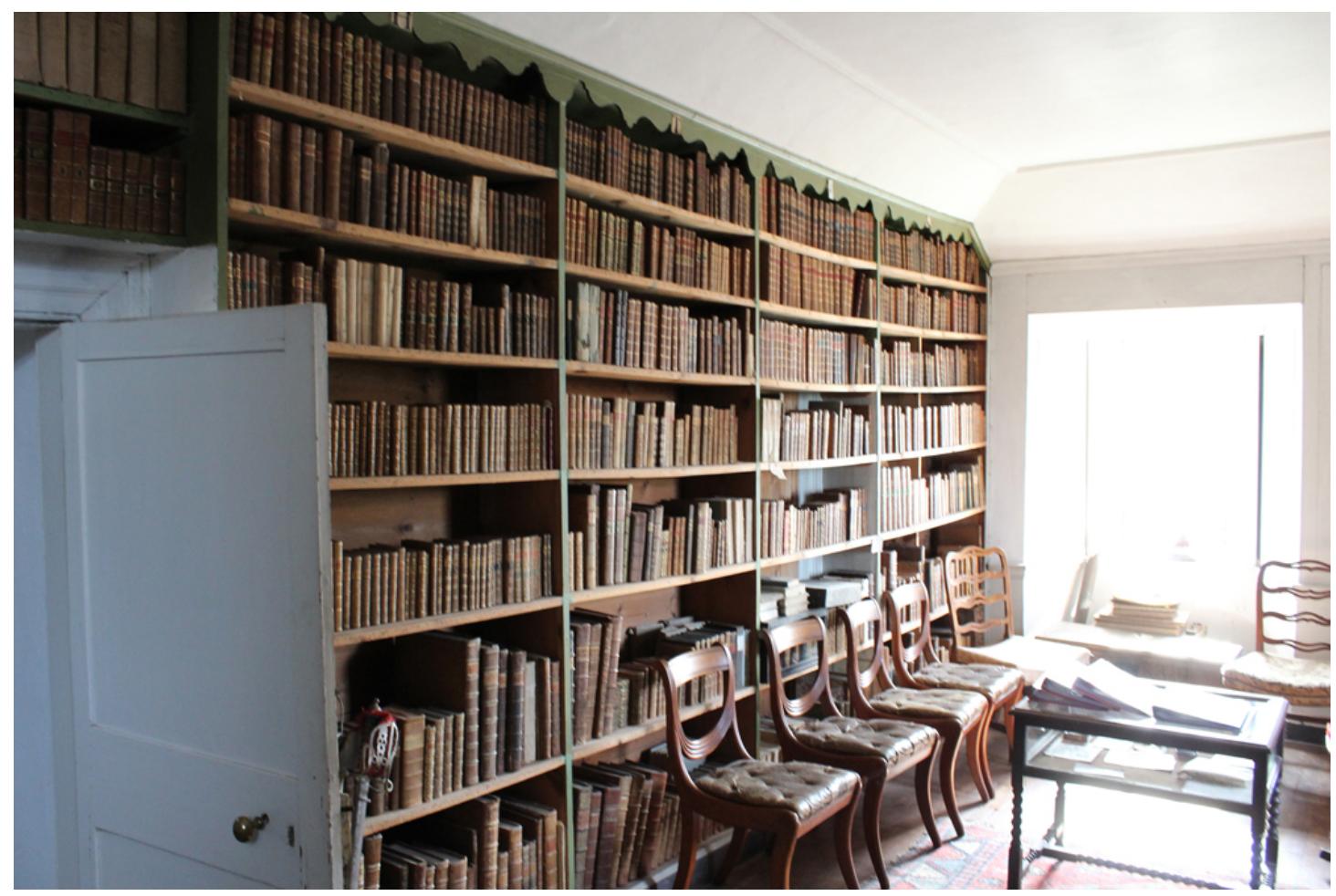

FIG 3: the 'skied' library on the top floor of one of the towers of Craigston Castle, Aberdeenshire. Photograph: Author.

This preference for libraries on upper floors of houses was in direct contrast taste in England where new houses were being designed with libraries on the piano nobile; Ragley Hall, Warwickshire, designed 1678, had the library to the north of the grand entrance hall. Yet, in Scotland, houses were still being designed long after this date with high central rooms intended as libraries. At the House of the Binns in West Lothian, the House of Dun in Angus, and Haddo in Aberdeenshire, rooms intended as libraries were located on the upper stories, maintaining the notion of skied libraries. One of the most notable examples of this is the book room at Foulis Castle, seat of the Chief of the Munros, in Ross-shire where an extraordinary "fifth-story octagonal chamber at the apex of the seventeenth century tower most dramatically combines books with a view". ${ }^{27}$ Duff House in Banffshire, designed in the 1730s by William Adam, saw the library move down several stories to the piano nobile but in the eastern quadrant pavilion reached by a curved colonnade passage rather than in the central block so that it was still away from everyday domestic activities. ${ }^{28}$ However, Adam and his client, Lord Braco, fell out and the wings were never built; the library was later installed in a gallery on the top floor of the main block.

The discussion of the location of libraries helps us understand the way in which these collections were viewed by their owners. Few examples of private libraries survive 
from the first half of the seventeenth century and certainly no extant book rooms' from that period exist. Yet, the fragmented evidence of private libraries of this period still offers a glimpse of society that goes beyond just owners and their books. The study of private libraries is often said to provide insight into education and tastes at particular times in history as well as helping to understand the characters and motivations of those who built them up. Durkan and Ross describe their earlier examination of books and their owners as a means of shedding light on "the mental history of a time when so many unchecked assumptions can be made". ${ }^{29}$ This notion of a library encapsulating intellectual tastes and accomplishments is often the underpinning theory given for the examination of extant library catalogues (and particularly those from the early seventeenth century onwards when private libraries begin to emerge more fully formed as we would understand them today). MacDonald, in his study of Drummond of Hawthornden's library, argues that the study of private libraries offers a better understanding real historical bibliography than any study of other libraries. He contends that private libraries show "the wider variety of popular stuff printed bought and read (but excluded from formal libraries like Sir Thomas Bodley's). ${ }^{30}$ Although the extent to which generalisations can be made from one private collection to another may be limited, it is the case that the examination of surviving catalogues and collections does provide a valuable picture of historical bibliography as well as the intellectual and literary tastes of the time.

William Drummond of Hauthornden (1585-1649) came from a well-connected gentry family whose seat was Hawthornden Castle on the River Esk in Midlothian. He had grown up surrounded by books as his father, J ohn, had a small number of volumes in his possession, including many of a practical nature on law, medicine, and agriculture but also famous works such as Sir Philip Sidney's Arcadia (1590), Lyly's Euphues (1579), the anthology England's Parnassus (1600), and Golding's English translation of Ovid's Metamorphoses (1567). His early passion for books is indicated by him in his Memorialls in which he notes his fear of blindness: "By reading Heliodorus and other bookes the 17 yere of my age I had a pain in myne eyes for the space of eight dayes". 31

Drummond is best remembered today for his poetry with Cypresse Grove (1619) being his most famous work and one in which he demonstrates a considerable command of the English language. His library continues to exert considerable 
interest for historians on a number of levels. These have been summed up best by RH MacDonald who wrote the definitive study of Drummond's book collection:

Drummond's library is a sample of early seventeenth century taste, one man's choice, but balanced and satisfyingly complete. It was collected in an age when it was still possible to take all learning for one's providence, and when all that learning could be assembled without great expense on the shelves of one room. Drummond's interests were typically catholic. His command of languages was unusual, but if in this he had more ability than had his intellectual contemporaries, his taste was nevertheless representative. He followed the fashions, but he did not forget the academic authorities in each field of learning. Nor can he be regarded as eccentric or especially scholarly: his considerable knowledge of the classics was commonplace at the time, and other educated men followed the courtly fashion by adding fluency in Italian, French and Spanish to their accomplishments. ${ }^{32}$

MacDonald perhaps overstates the idea of an encyclopaedic library and also downplays the cost of materials. It is, however, the case that Drummond made many of his book purchases in France where the cost of volumes was approximately half that of England or Scotland. It is clear that Drummond had acquired approximately one-third of his library by 1608 when he returned from France as a young man. His autograph catalogue of 1611 lists 546 titles and he listed the prices of some 401 of these (323 bought in France and 76 bought in England). He paid 2,399 sous for the French books ( $€ 10$ 18s) and $£ 6$ 13s 7d for the English ones. ${ }^{33}$ This difference in the cost of books between England and France seems to have been typical. Ten years later, Henry Erskine, who was emulating Drummond by completing his education by studying law in Paris and in Bourges, wrote to his father the Earl of Mar:

I will not be prodigall in nothing except in buying bookes, and yit none bot suche as shall be necessaire, and I asseure myeselfe that your Lordship will allow me this, seeing that it was be your commande that I followed my studies in France. ${ }^{34}$

MacDonald analysed the purchasing habits of Drummond demonstrating that price was not the only motivating factor for buying on the Continent; the selection was far wider than in Scotland or England:

Drummond bought two Italian books in Scotland, 18 in England and 39 in France. The figures for other subjects are in the same pattern: in Greek, 20 in France, 11 in England; in Hebrew, 5 in France, none in England; in theology, 10 in France, none in England; in law, 14 in France, none in England; in philosophy, 27 in France, 10 in England; poetry, 30 in France, 6 in England; prose, 69 in France, 11 in England. 35 
Drummond's buying was sophisticated but he had one eye firmly on cost. This is not entirely surprising; when Sir J ohn Drummond, William's father, died in 1610 he left a little over $£ 14,000$ Scots to his heirs so the Drummonds were not vastly wealthy. The good deals to be had on the Continent, together with the range of materials, continued to be a draw for other book collectors throughout the seventeenth century with Andrew Fletcher of Saltoun making substantial acquisitions during his sojourns in France, Spain and the Low Countries, adopting a purchasing approach not vastly dissimilar to Drummond.

Drummond's library has, on occasion, been dismissed variously as an "oddity" or "a freak". ${ }^{36}$ Miss Bald, the originator of these views, believed that Drummond's library was hardly "evidence of a general Scottish interest in fine literature"37 and that his tastes were "infinitely removed from that of his Scottish contemporaries". ${ }^{38}$ It is difficult to make hard judgements on this as there are so few extant catalogues of private Scottish collections from this period. The Bannatyne Miscellany contains details of private libraries: Adam King, an advocate was valued at $£ 1,440$ Scots, David Ferguson and Thomas Buchanan both ministers had libraries of $£ 100$ and $£ 300$ respectively. ${ }^{39}$

Drummond did, however, put together a large and diverse collection with MacDonald identifying 1,405 volumes of an estimated 1,600 in total (some 200 or so having been lost from Hawthornden at some point) and this compare well with English collections. Sears J ayne in Library Catalogues of the English Renaissance records only a few men in England with collections larger than this and those who did so where from the higher nobility. In terms of coverage and scope, MacDonald equates Drummond's library with those of Sir Edward Coke, Henry Percy, 9' ${ }^{\text {th }}$ Earl of Northumberland and Sir Thomas Knyvett in England. ${ }^{40}$ Yet, in terms of value it was more modest than many English collections. MacDonald identifies the inherent difficulties which exist in comparing number of volumes with monetary value, particularly when accurate details of imprints and bindings may be absent.

In spite of all of this, Drummond's library remains of singular importance in the story of private libraries in Scotland, irrespective of debates about its representativeness. He was clearly a serious book collector and took interest in the cataloguing of the works with his first autograph list being compiled in 1611. He was also interested in the taxonomy of classification and arrangement of the items, according to language first and then by subject (philosophy, law, theology, poetry and prose); this was an 
approach used by most librarians at the end of the sixteenth and beginning of the seventeenth centuries and was analogous with Draud's catalogue of the Bodleian in 1605. Drummond gave away much of his collection in his lifetime to the Tounis College in Edinburgh. ${ }^{41}$ The remainder of the collection had a mixed fate: Drummond's son retained a good number of his books but the fortunes of the collection changed in the eighteenth and nineteenth century. Some were removed by Bishop William Abernethy (husband of the last Drummond descendant) to his diocesan library in Brechin; the remainder of the Hawthornden library was sold, in a piecemeal fashion, during the nineteenth century.

\section{'Patriots and rogues'}

It was during the turbulent political climate of the late seventeenth century that one of Scotland's greatest patriots and greatest book collectors emerges. Andrew Fletcher of Saltoun (c.1653-1716), the son of an East Lothian laird with good connections, established for himself a reputation as both a great Scottish patriot and one of the nation's pre-eminent political theorists, speaking articulately and vociferously against the Union during the early 1700s. His opposition the prevailing political establishment through the last quarter of the seventeenth century led him to spend much time in exile. Fletcher the exiled patriot became one of the nation's greatest book collector, amassing a library which was unsurpassed in his lifetime. Fletcher's love of books can be traced back to his early education which was undertaken by successive ministers at Saltoun, Patrick Scougall (later Bishop of Aberdeen) and Gilbert Burnett (later the famous Bishop of Salisbury), before matriculating at St Andrews University.

Fletcher spent much of the next ten years, until 1678 on the Continent with bills and receipts in the Fletcher Papers ${ }^{42}$ showing him to be, for example, in Paris, The Hague and Rotterdam at various points in the 1670s. It was in these countries that he spent considerable time and resources purchasing books. The seeds of his learning sown by Scougall and Burnett now flourished. Fletcher's collecting appears to have started in the mid-1670s and he spent the next forty years amassing what was probably one of the largest private collections of its time. In these forty years, he purchased around six thousand volumes. Willems, in his study of Bibliotheca Fletcheriana, estimates that around 4,800 volumes date from before 1675 with the remaining 1,200 being contemporary. From this, it is clear that Fletcher was interested in collecting old books. The collection contained some forty-eight incunabula, of which a significant proportion of which were Italian in origin. 
This active approach to book-buying enabled Fletcher to put together an extraordinarily diverse and rich collection. He had a real instinct for collecting the rare and the curious and his time scouring the premises of antiquarian booksellers in Paris, Leiden, Rotterdam and The Hague clearly paid off. He had over one hundred Aldus imprints, eight first editions of Galileo and twelve of Kepler. ${ }^{43}$ His time in Spain enabled him to acquire some very rare and often very obscure titles which were, in all probability, unique in Scotland at the time; these include Argensola's Conquista de las islas Malucas (Madrid, 1609), Gracian's El Discreto (Huesca, 1647) and de Herrera's Versos (Seville, 1619). He also often displayed judicious discernment with the contemporary works he acquired. The purchase of Dutch material (72 from Rotterdam and 29 from The Hague) is an example of this with volumes such as Vauban's Directeur de fortifications (The Hague, 1685) or Abbadie's Traité de la verité (Rotterdam, 1684) becoming prized and rare items.

His library represented his own personal interests and preoccupations with historians, poets, orators and legislators to the fore and less space for theology, physics, mathematics and law. Classical authors were, inevitably, heavily represented although there is considerable debate about how well-versed Fletcher was in Greek; in his late forties he confessed to his brother, Henry, that he happily exchange knowing it "for all the knowledge I have of anything". ${ }^{44}$ Fletcher also collected some extraordinary rarities for a Scottish laird with, for example, his extensive collection of contemporary Hungarian histories (from the 1680s and 1690s) being particularly noteworthy. His library was clearly influential in his own writings during the 1690s and beyond. His tracts included Two Discourses Concerning the Affairs of Scotland (1698) where he unpicked the economic crisis afflicting his homeland.

There is some speculation about where and, indeed, how Fletcher's books were housed. In all probability, they were shipped back to Saltoun Hall in East Lothian. The present house dates from the 1760s and included a grand library but this was constructed fifty years after Andrew's death. He did, however, maintain running catalogues of the collection and his approach to organisation may well have been influence by Gabriel Naudé. As Willems notes ${ }^{45}$ his two autograph lists display great bibliographic knowledge and a familiarity with classification. One of these lists (NLS MS1784) covers history and literature and demonstrates clear taxonomy and detail sub-classification with, for example, Historia given very detailed sub-headings including both geographical and chronological divisions. In the second autograph 
list, Fletcher uses eight main classes: Historia, Poetae, Oratores, Theologi, Legislatores, Physici, Mathematici and J uridici. ${ }^{46}$ The catalogues demonstrate that he was more the just a book collector and give a real insight into the organisation of one of the outstanding private libraries in Scotland.

For as much as Andrew Fletcher of Saltoun was an opponent of the Union, James Ogilvy, $4^{\text {th }}$ Earl of Findlater and $1^{\text {st }}$ Earl of Seafield was one of its staunchest supporters (although within seven years of its passing into law he was calling for its repeal). He served in many of the senior legal offices in Scotland including Solicitor General and Lord Chancellor at the time of the Union. Although his detractors would undoubtedly claim Seafield as one of the 'chief rogues' in that famous parcel of them, he himself was sanguine about the Union and famous tapped the Act with the royal sceptre after it had received Royal Assent and uttered the words for which he has become best remembered for "Now there's the end of an auld sang". ${ }^{47}$ Seafield, like many a lawyer, bought books because they served a purpose for him rather than because he was a particular collector. The collection he established at Cullen House in Banffshire and which survived completely intact until 1975, contained a wide range of Scots, English and European legal works dating from his time. These included the kind of materials one might expect such as Thomas Murray's Laws and Acts of Parliament of Scotland (Edinburgh, 1681), twelve volumes of British Acts of Parliament (Edinburgh, 1718-33), Nalson's Impartial Collection of Great Affairs of State (Edinburgh, 1682) and Statutes relating to excise upon Beer and Ale (Edinburgh, 1724).

Seafield was almost unique in his family in that he collected earlier material. Amongst the earliest items in his collection was a copy of Guilielmus Budaeus's Annotationes Priores et Posteriores (Paris, 1556) and Antonio Bonfini's Rerum Ungaricum (Frankfurt, 1581 and 12 after its first publication in Basle by Sambuca). However, these like his other acquisition were for a purpose and he created, like many other Scottish legal families, a working library. John Macky, that veritable chronicler of the nobility of the time, described him "a gentleman of great knowledge in the civil law and the constitution of the Kingdom"48 and testimony to this description was to be found in his library. History, however, has judged the architect of the Union much less favourably. 


\section{Enlightenment}

The religious turmoil which had dominated Scottish life since the middle of the sixteenth century a period of political upheavals. The Act of Union in 1707, was followed quickly by the abortive J acobite Rising in 1708 and by more dangerous ones in 1715 and 1719. Despite, or perhaps because of, this political tumult, the eighteenth century was a period of extraordinary cultural flowering in Scotland, even allowing for the vacillation between the Unionist and Jacobite causes. The reasons for the Union and the aftermath of it, stretching across the decades, are too well known to required rehearsal here.

By the middle of the eighteenth century, around three-quarters of the Scottish population were literate and Towsey, in his study Reading in the Scottish Enlightenment, highlights that this was a very book-orientated culture. ${ }^{49}$ In 1728, Allan Ramsay the Father (1686-1758), the poet and wig-maker, opened Scotland's first circulating library in Edinburgh's Luckenbooths. Studies of libraries in the Enlightenment have tended to focus on what Towsey describes as the celebrity libraries of their day. The towering figures of David Hume and Adam Smith have inevitably received much as a means of amplifying their intellectual biography. In addition to Hume and Smith, were great jurists such as Lord Kames and Lord Monboddo, philosophers such as Francis Hutcheson, Dugald Stewart and Adam Ferguson, divines such as Hugh Blair and George Turnbull, engineers such as J ames Watt, geologists such as James Hutton. The Enlightenment spread firmly into the visual arts with painters like Allan Ramsay (the Son) and Henry Raeburn, architects such as Robert Adam and, of course, with poets and novelist Robert Burns and Walter Scott. Many of these belonged to lairdly families, but many did not.

However, arguably more interesting than the study of the celebrity collections, is the investigation of what libraries looked like in other parts of Scottish society at this time. Towsey surveyed the 450 surviving library catalogues from the Enlightenment period categorizing them as professional (including clergy, law, medicine and academic) 97, titled (including peers, baronets, law lords and knights) 83, gentry 72, subscription libraries 51, merchants 25 , circulating Libraries 21, manufacturers 13 , tradesmen 11, religious or endowed 10, and women 6. Some of these categories clearly overlap (particularly with professional legal libraries often belonging to men who came from the gentry class and Newhailes may be said to be good example of this). The blurring of social distinctions with mercantile and professional men often 
being the scions of landed families and many more having aspirations to join that class is a key characteristic of the period.

By the second half of the eighteenth century the nature of the private library (including in country houses) had changed significantly from the closets and cabinets of the sixteenth and seventeenth centuries. The library Newhailes marked the inclusion of the room in the principal or family apartments. When Robert Adam constructed Mellerstain House in Berwickshire, the library had moved from the corner of the axis of honour (or from its habitual skied position elsewhere) right to the centre of the house. At Mellerstain it is right next to the principal saloon. In this, there was clear emulation of prevailing English design. In the 1740s, William Kent included the library in the family wing of Holkham Hall in Norfolk and it was clearly intended as the principal sitting room. Girouard, although addressing English houses, offers us the reason for this:

Books had ceased to be the accoutrements of the expert and had become an everyday part of upper-class life. The library and its content were no longer the personal equipment of the owner of the house; they had become the common property of the family and his guests. ${ }^{50}$

The early library closets were rooms for study and contemplation. By the Age of Enlightenment, they had become sitting rooms, at the heart of family life. Libraries could

...just like any other room in the house, act as rooms of display - displaying wealth, the ability to collect, and the intellectual achievements and knowledge to which the country house owner would lay claim". ${ }^{51}$

Some notable exceptions to this change were planned however. Sir J ames Clerk of Penicuik (1709-1782), the heir to an Enlightenment family with strong links to Edinburgh's intellectual scene, rebuilt his family seat in the 1760s and 1770s. The culmination to his rebuilding was to be a Roman Pantheon in the policies in which would be housed his library; it was not, alas, built.

Generally, however, the private library gradually became an everyday room as the positioning of the room at Mellerstain (1770), Gosford House (1791) and Kennet House (1793) ${ }^{52}$ all demonstrate. Scottish lairds would also be depicted in their libraries, emulating Hogarth's portrait of the Cholmondeley family, surrounded by their book collections. William Robertson's group portrait of the family of Sir Archibald Grant of Monymusk in Aberdeenshire, shows them surrounded by books, 
globes, telescopes and other artefacts designed to show their learning and their curiosity and that their library was at the heart of the home. ${ }^{53}$

Monymusk House offers interesting lessons for the student of lairdly libraries in Scotland at the time. Like many country houses throughout the country, the library was available to a wider section of local society than might be at first thought. The borrowing of books from country house collections was common in the eighteenth and nineteenth centuries. A number of borrowing lists survive with those for Craigston Castle in Aberdeenshire and Brodie Castle in Morayshire being particularly detailed. Towsey describes these lists as providing evidence that

"the family library was one of the main focuses of genteel sociability in rural Scotland, with 'privy' borrowing readily extending to other neighbouring families". 54

However, many of these registers (Brodie in particular) also demonstrate connections with and borrowing by a far wider group that traditional neighbouring lairds with evidence of local 'professionals' such as physicians and lawyers in local county towns also borrowing books. Towsey rightly asserts that this was linked to social prestige as much as intellectual endeavour when he says:

Clearly books were one of the ways by which such individuals and families engaged with each other - allowing them to impress their neighbours with their impeccable taste, as well as providing ample materials on which to base their polite conversation and sociable interaction. ${ }^{55}$

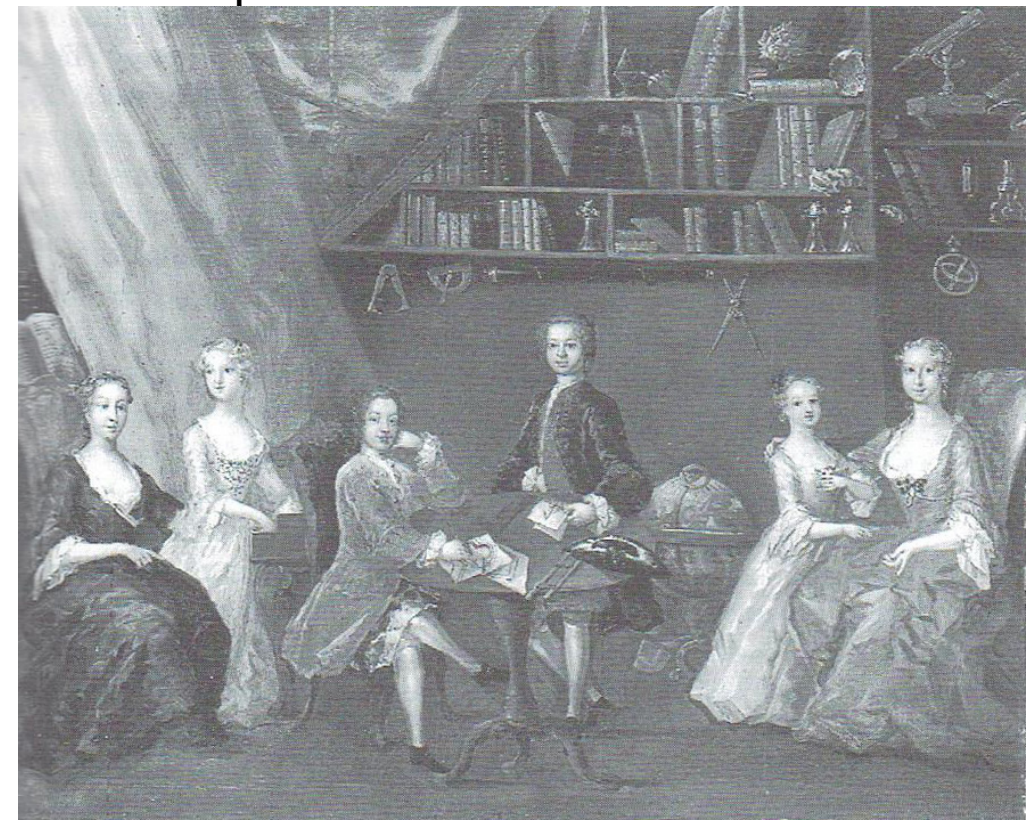

FIG 4: The Grant family in their library at Monymusk House, Aberdeenshire in the early 1740s. Private Collection. 
Borrowing was not, however, without its perennial difficulties and the problem of people not returning volumes complicated the lives of many owners. Lists of missing books are commonly found in many Scottish Estate Papers. At Monymusk, the problem of non-returns bedeviled the Grant family with Sir Archibald Grant have a notice printed for circulation around the county:

Whereas many Books have been borrowed from the library of Monymusk, and have not been Returned, which renders many sets incomplete, it is entreated that those possessed of such would return them immediately to Monymusk house or to the Publisher of this paper - and if any by accident should appear at sales with the familys Arms or Sir Archibald Grants Name in them - beg that they may be retained or that the family or Publisher may be acquainted which will be Gratefully acknowledged. ${ }^{56}$

The library at Brodie Castle was much used by neighbours during the eighteenth and nineteenth centuries. During the eighteenth century, Alexander 19th Brodie of Brodie had been appointed Lord Lyon King of Arms, in spite of the fact that he demonstrated both a woeful ignorance of, and lack of interest in, heraldry and genealogy. Alexander did buy one or two volumes on heraldry, but these were superficial works that dealt with the subject as an art form rather than a serious science. The range and depth of the library at Brodie is interesting on many levels not least for its extensive runs of various magazines. The Lyon Brodie had started subscribing to The Scot's Magazine in 1739 and his two successors continued purchasing it. Subsequent lairds also subscribed to The Gentleman's Magazine, to Fraser's Magazine and subsequently to Blackwood's.

James, the 21 2 st Brodie had a reign of sixty-five years and added significantly to the collection making it very typical of a country house library of the time with works such as Smollet's History of England, Rousseau's Oeuvres (Geneva, 1782) and later the ubiquitous Waverley Novels. He also acquired some of the famous British Poets series (around twenty volumes rather than the full set). He added many older editions to the library at Brodie. Most prominent amongst these is a beautiful 1650s edition of Codicis J ustiniani (Amsterdam: Elsevier). J ames was also responsible for buying the oldest work in the collection, a fine copy of Epigrammatum Græcorum (Basle: Froben, 1549). Some of the purchases came from novel sources, Brodie almost certainly bought up material from subscription libraries for his set of The Annual Register, (1770 to 1804) all bear a bookplate with the words "This book belongs to Forres Subscription Library". 57 
By the close of the eighteenth century the lines of distinction between those in trade and landed proprietors had become seriously blurred with more and more country estates being purchased by those who had made their fortunes in mercantile pursuits. The law had always been a suitable 'profession' (such as the Dalrymples at Newhailes or the Dundases at Arniston) but now those merchants were more readily accepted as part of the landed class than ever before. With this came, the desire to have the attributes of the refined gentleman, a country house, a landscaped park, works of art, fine furniture and, in very many cases, a library. Towsey notes some interesting examples of this class of collector, Patrick Miller of Dalswinton and Henry Monteith of Carstairs, both merchants who became landed proprietors. To this might be added J ames Brander who returned from Lisbon having made a fortune and built Pitgaveny House in Morayshire, or David Steuart, the Edinburgh businessman, a scion of a minor gentry family, who established what was described by Cornelius Elliot, the Edinburgh bookseller, as "the most uncommon and certainly the most valuable private library ever brought to the hammer on this side of the Tweed". ${ }^{58}$

Yet, in spite of the commercial wealth of people like David Steuart, the traditional landed families were still committing to major library projects (collections and buildings). The Earls of Erroll added a double-height library to Slains Castle in the mid-nineteenth century. The room was to house their long-established library at the nucleus of which was the library of Bishop J ames Drummond of Brechin (1629-1695) a seventeenth century clergyman sheltered by the Erroll family after the overthrow of the episcopacy. The Slains collection also included the extensive collection of the noted bibliophile, Alexander Falconer, who had married the $14^{\text {th }}$ Countess. ${ }^{59}$ An equally grand double-height library was commissioned by Alexander Lindsay, 25th Earl of Crawford and Balcarres (1812-1880) for Dunecht House in Aberdeenshire. Crawford amassed an important library of over 30,000 volumes and was remarkably similar in approach to the $3^{\text {rd }}$ Duke of Roxburghe; he collected out of interest rather than because of a desire to own rare books. Any intentions to move the library from Crawford's English seat, Haigh Hall at Wigan, were dashed by his death in 1880. He was buried at Dunecht. However, his body was stolen and some months later was found in ditch. All affection that the Crawford family had for Dunecht soon evaporated and the library never moved north. 


\section{Decline}

The Crawford family's abandonment of Dunecht happened at the same time as the first major signs of decline occurred with dispersal and eventual demolition of Scotland's greatest private house, Hamilton Palace, the Lanarkshire seat of the Dukes of Hamilton and Brandon. This vast edifice was demolished shortly after the First World War but had long-since lost many of its greatest treasures to the sale rooms. The Hamilton Library; this was essentially the collection of his ancestors to which the Duke had added. It was, however, on scale far beyond the libraries of most lairds. The Hamilton grandeur was not to last, however, In 1882, the $12^{\text {th }}$ Duke was finally compelled to pay for the extravagance of previous generations and an enormous sale of contents from the palace, lasting seventeen days, took place in July 1882.

Despite times having become tough, some outstanding libraries continued to be developed. Archibald Primrose, 5th Earl of Rosebery (1847-1929), Prime Minister between 1892 and 1895, was an avid collector, with standing orders with many wellknown booksellers, had inherited a fine collection at Dalmeny House but supplemented this with a collection a Barnbougle Castle, his private retreat on the Dalmeny estate and at the Durdans, his home near Epsom. He was particularly interested in Mary Queen of Scots but he also amassed a rare collection of Scottish pamphlets (over two-thousand) covering history, politics and society between 1585 and 1923. Rosebery presented the collection at Barnbougle to the newly-established National Library of Scotland in 1927. Much of his "English" collection was sold at auction in late 2009.

The collection at Keith Hall in Aberdeenshire, lineal descendants of the great Earls Marischal at Dunottar Castle, had an extensive collection and the late Earl of Kintore lamented his "extremely selfish forebears"60 for selling the collection in the middle of the twentieth century. For the Earl the sale was compounded by the fact that the Aberdeen bookseller who purchased it promptly went bankrupt and the entire collection was resold and completely dispersed at very low prices.

The Seafield family at Cullen House in Banffshire had continued to collect extensively across the eighteenth and nineteenth centuries. Their interests in legal texts had not entirely diminished after the death of the $1^{\text {st }}$ Earl but his successors displayed a marked preference for Scottish and European history. As with many country house libraries there was a noted predilection for French and Italian material. The fact that the 7 th Earl of Findlater and $4^{\text {th }}$ of Seafield lived for some time in Germany toward 
the end of the eighteenth century, resulted in the collection acquiring some interesting German works including fine German first editions from the 1780s. The collection at Cullen House contained only a small number of religious, theological or doctrinal works. Although it contained the usual range of classical works, geographies and travelogues, it also contained a disproportionately small number of works of fiction with few novelists (Scott being the exception, of course) being present in the collection. Nevertheless, by the turn of the twentieth century the collection exceeded 10,000 volumes and occupied two interconnecting rooms

In 1975, the Earl of Seafield finally parted company with the house and its contents were auctioned in a series of sales. The library sale took one day and virtually all of the books were sold with Lord Seafield retaining only a small number. ${ }^{61}$ It is difficult not to believe that had Cullen been slightly closer to London, the dispersal of its collections would have provoked more comment than it did. It was sold at the same time as the Mentmore furore was preoccupying the heritage groups and consequently the sales provoked little comment nationally although the local concern was intense. A few years earlier, in the 1960s, the Fletcher family had similarly sold Saltoun Hall and, like Cullen House, it was converted into apartments. These sales proved a final, ironic coincidence in the story of Fletcher of Saltoun and Lord Seafield in that the libraries of two such notable Scots who had jousted against each other in the political arena should be dispersed in the same way and at the same time.

\section{Conclusion}

This article provides observations on the libraries of a number of Scottish lairds from the middle of the $16^{\text {th }}$ century. Some of these collections are rightly well-remember and have been studied in some depth. This is particularly true of both Drummond and Fletcher. However, the collection of William Forbes of Tolquhon has, apart from one study in the 1930s, gone largely unrecorded. Yet it offers, as indeed the others do, considerable evidence of that many Scottish lairds were following the intellectual trends of their time and building significant libraries and collections of books. Importantly, these collections demonstrate the strong links which existed between Scotland and continent Europe. This link has previously been well-established in the case of collectors such as Andrew Fletcher of Saltoun, but here it is reinforced, a century earlier, by William Forbes of Tolquhon. The strong mercantile links which existed between the ports of the east coast of Scotland and the Baltic and the Low Countries, were mirrored by intellectual links. 
It is undoubtedly the case that there is considerable scope for further investigation into these lesser-known' libraries, particularly in instances where they survive in other institutions (e.g. the Newhailes collection in the National Library of Scotland or the Meldrum House collection in Aberdeen University). However, there are many lesser known collections such as that at Craigston Castle in Aberdeenshire which are worthy of study. There is much more to be discovered about the book collecting and reading habits of Scottish lairds and their families. This branch of library history may be focused on an elite group in society, but further scholarship in this field has the potential to offer much to our understanding of rural society in Scotland.

\section{Notes}

${ }^{1} \mathrm{~J}$ ohn Durkan and Anthony Ross, Early Scottish Libraries. Glasgow: J ohn Burns and Sons, 1961) also. John Durkan and Julian Russell "Additions to J. Durkan and A. Ross, 'Early Scottish Libraries, at the National Library of Scotland," The Bibliotheck; a Scottish J ournal of Bibliography and Allied Topics, 11, 2 (1982): 29-38.

${ }^{2}$ Initially, J ohn Burke's first publication on those landed families below the Peerage and Baronetage, had been called Commoners of Great Britain and Ireland (1833-38) and only with the second edition was the more flattering term of Landed Gentry adopted.

3 Sir Thomas Innes of Learney. Scots Heraldry. (London: Oliver and Boyd, 1956), 2.

${ }^{4}$ Robert Louis Stevenson. Kidnapped. Rockville MD: Serenity, 2009 p57.

5 Innes of Learney, 2.

${ }^{6}$ Site visit to Tolquhon Castle, Aberdeen, May 2017. See also W. Douglas Simpson, Tolquhon Castle and its builders, (Edinburgh: Proceedings of the Society of Antiquaries of Scotland, 1938) 248-271.

${ }^{7}$ Simpson, 251.

8 Ibid, 251-252

9 Ibid, 251

$10 \mathrm{~J} \mathrm{ohn} \mathrm{Forbes-Leith} \mathrm{to} \mathrm{James} \mathrm{Beattie} \mathrm{from} \mathrm{Whitehaugh.} \mathrm{Beattie} \mathrm{Papers.} \mathrm{University} \mathrm{of}$ Aberdeen Special Collections. MS 30, 1-53, 2-327, 26 April 1779.

11 Ibid.

12 Notes and Queries. (Series 2, VIII(193) September 10 1859), 203-204.

13 Simpson, 252

14 Notes and Queries, 203-204.

${ }^{15}$ Durkan and Ross, 77-78; and also Simpson, 252.

16 The imprint being a folio edition, Basel: Henricus Petrus, March 1535.

${ }_{17}$ Durkan and Ross, 45 and Simpson, 253.

${ }^{18}$ Bishop Reid's books are discussed by Durkan and Ross, 44-47. He is also covered in many articles in The Innes Review (the journal of the Scottish Catholic Historical Association) including. J ohn Durkan. "The beginnings of Humanism in Scotland", The Innes Review 4, 1, (1953), 5-24 and J ohn Durkan, "The cultural background in sixteenth century Scotland", The Innes Review, 10,2, 283-439.

19 Simpson, 253.

20 Simpson, 255. Two other volumes from the collection were identified by Simpson as being (1937) in the possession of Miss Fyers, Kirkton of Maryculter, Aberdeenshire, a descendant of the family. One was Cronique et Mirouer Hystorial de France, (Paris: Nicolas de la Barre, 1518) and had autograph provenance marks of Williame Forbes of Tolquhon, 1588, J ohn Forbes Leith of Whitehaugh, 1778 and also J hone Meldrum, Marchemond Herald and Thome Meldrum, Burgis of Aberdeen. The second was a folio Bible (London: Christopher Barker, 1583) bearing the signature of George Ogilvie. William Forbes the $12^{\text {th }}$ and last laird of Tolquhon entered the particulars of his marriage to Anna Leith of Whitehaugh together with the names and dates of their children - three sons and two daughters - all of which had subsequently been blacked out. These volumes were acquired by Aberdeen University Library 
after Miss Fyers's death. Subsequently, another volume from the Tolquhon library, De ScripturæSanctæ(Zurich, 1538), was found in Aberdeen University.

${ }^{21}$ He being, almost certainly, the same George Ogilvie referred to by J ohn Forbes Leith in his letter to J ames Beattie almost two centuries later.

22 Traditionally, the wives of Scottish lairds are referred to as "Lady" followed by the placename (the territorial designation). So the wife of Forbes of Tolquhon would be Lady Tolquhon and never Mrs Forbes. Similarly, Byron's grandmother was never 'Mrs Gordon of Gight' and always 'Lady Gight'. (Ironically, it being the neighbouring castle to Tolquhon). This is a courtesy and not a title of nobility. The Laird would be addressed by his territorial designation. A letter, from 1950, viewed during this research saw the Lord Lyon King of Arms still begining his salutation 'Dear Cairnfield' rather than 'Dear Colonel Gordon'.

${ }^{23}$ McKean, C. The Scottish Chateau: the country house of renaissance Scotland. (Stroud: Sutton, 2001), 74.

24 Ibid. 173, see also Sir Arthur Mitchell and James Clark (eds). Geographical collections relating to Scotland made by Walter MacFarlane. (Edinburgh: Edinburgh University Press, Constable and Scottish History Society, 1907-08). Volume 3, 223.

${ }^{25}$ Mark Girouard, Life in the English country house, (Harmondsworth: Penguin, 1980) 166; also, Sears R J ayne, Library catalogues of the English Renaissance, (Berkeley: University of California Press, 1956) 93-172.

26 Ibid. Girouard 166.

27 McKean, 74.

${ }^{28} \mathrm{~J} \mathrm{ohn} \mathrm{Connachan-Holmes,} \mathrm{Country} \mathrm{houses} \mathrm{of} \mathrm{Scotland.} \mathrm{(Argyll:} \mathrm{House} \mathrm{of} \mathrm{Lochar,} \mathrm{1988)} 40$.

29 Durkan and Ross, 5.

30 Robert H MacDonald, The library of Drummond of Hawthornden, (Edinburgh: Edinburgh University Press, 1970) p2.

31 Robert H MacDonald, (ed), William Drummond of Hawthornden Poems and Prose. The Association for Scottish Literary Studies, 6 (Edinburgh \& London: Scottish Academic Press, 1976) which includes the text of the "Memorialls".

32 MacDonald, The library of Drummond of Hawthornden, 2.

33 Ibid. 37

34 Royal Commission on Historical Manuscripts, Report on the Manuscripts of the Earl of Mar and Kellie, (London: HMSO,_1930) 97.

35 MacDonald, The library of Drummond of Hawthornden, 37.

36 MA Bald, Venacular Books imported into Scotland, 1500-1625, The Scottish Historical Review XXIII 1926, 254-267.

37 Ibid, 255.

38 Ibid, 262.

39 The Bannatyne Miscellany, (Edinburgh: Bannatyne Club, 1836) Volume II, 191. This volume contains, 186-294, considerable details on inventories of properties and wills of booksellers and printers. cf MacDonald, The library, p44.

40 MacDonald, Ibid.

41 These items - catalogued as Auctarium bibliothecae Edinburgenae (1627) - remain in Edinburgh University Library.

42 Fletcher of Saltoun Papers (National Library of Scotland MSS 16501-17900) MS16503.

43 PJ M Willems, Bibliotheca Fletcheriana or The extraordinary library of Andrew Fletcher of Saltoun. Wassenaar, Published Privately, 1999) xii(e).

44 Fletcher of Saltoun Papers, Ibid MS 16502, fol. 172.

45 Willems, iv.

46 Fletcher of Saltoun Papers Ibid MS 17830.

${ }^{47}$ Attributed to Seafield and for which he is best remembered.

${ }^{48} \mathrm{~J} \mathrm{ohn} \mathrm{Macky,} \mathrm{Memoirs} \mathrm{of} \mathrm{the} \mathrm{secret} \mathrm{services} \mathrm{of} \mathrm{J} \mathrm{ohn} \mathrm{Macky,} \mathrm{Esq;} \mathrm{during} \mathrm{the} \mathrm{reigns} \mathrm{of} \mathrm{King}$ William, Queen Anne, and King George I. [otherwise called in subsequent editions 'Characters']. London[s.n.] 1733

49 Mark Towsey, "An Infant Son to Truth Engage: Virtue, Responsibility and SelfImprovement in the Reading of Elizabeth Rose of Kilravock, 1747-1815". Journal of the Edinburgh Bibliographical Society, 2, 69-92.

50 Girouard, 180.

${ }^{51}$ Connachan Holmes, 50. 
52 Kennet House, Royal Commission on Ancient and Historic Monuments Scotland (RCAHMS) available at http://scotlandsplaces.gov.uk/record/hes/219332/kennethouse/rcahms (December 2017).

53 Mary Cosh, 'Organs, Orrerys and Others: a commission for Monymusk' in Ian Gow, and Alistair Rowan, (eds) Scottish Country Houses 1600-1914. (Edinburgh, Edinburgh University Press, 1995), 71.

54 Towsey, 60.

55 Ibid.

56 Library Motes at Monymusk House, National Records of Scotland GD345/ 800/ 10

57 Private Source.

58 Brian Hillyard, David Steuart Esquire: an Edinburgh collector. Edinburgh: Edinburgh Bibliographical Society and National Library of Scotland, 1993), 11.

59 One of the ancient Scottish peerages capable of descending through the female line.

60 Private Correspondence with Earl of Kintore, 1995.

61 Private Correspondence, 1995. 